intracellular freezing, it is considered that the permeation of such protective solute into a cell tends to protect it against frost injury. In order to clarify whethor this hypothesis can be also adopted in animal cells or not, I hope that some experiments will be made.

Institute of Low Temperature Science,

Akira SAKaI

Hokkaido University, Sapporo.

'Maximov, N. A., Ber. deutsch. bot. Gesell., 30, 52 (1912).

${ }^{2}$ Sakal, A., Low Temp. Sci., Ser. B. 17, 21 (1959).

'Sakai, A., Low Temp. Sci., Ser. B. 14, 17 (1056).

‘ Sakai, A., Nature, 185, 393 (1960).

\section{A Specific Effect of Copper on the Respiration of Chlorella vulgaris}

ON adding hoavy metal salts to cells of Chlorella vulgaris shaken in $10^{-3} M$ phosphate buffer, $p \mathrm{H} 6 \cdot 0$, the endogenous respiration often increased tornporarily but, with the exception of silver, high concentrations caused no respiratory inhibition for many hours. Copper, however, differed from all other metals tested (barium, manganese, nickel and lead inter alia) in that its effect on respiration depended on the environmental conditions during the period of treatment. If the suspensions of Chlorella were shaken continuously, $10^{-1} M$ copper sulphate was not inhibitory for 7-20 hr., but if the shaking was stopped, concentrations lower than $10^{-3} M$ rapidly became toxic. Experiments were carried out in respirometer flasks, using about $3 \times 10^{8}$ cells suspended in $3 \mathrm{ml}$. of buffer. Copper was determined by the method of Abbott and Polhillx. Copper sulphate was tipped from the side-arms, and shortly afterwards one set was brought to rest while the remainder was shaken for $3 \mathrm{hr}$. Thereafter, caustic soda was added to the centre wells of the flasks, which were then shaken for a further period during which respiration was measured. The toxic effect on unshaken cells increased if the treatment was carried out in narrow centrifuge tubes.

When the uptake of copper by cells in shaken and unshaken vessels was compared, somewhat more copper was found to be absorbed in a given time by the cells in stationary vessels, unless the time was short. This was probably due to the more rapid death of the cells in unshaken tubes, for dead cells absorb copper very readily (Table 1). These figures also show that the fall in respiration in unshakon vessels was not closely related to the amount of copper applied or to

Table 1. REspiration AND COPPER SORPTION OF Chlorella Celis AFTER TreatMENT WITH VARYing AMOUNTS OF COPPER SUlphate IN UNSTHKFN TUBES

Copper sulphate Oxygen uptake $4 \mathrm{hr}$. $\mu$ gm. copper/unit weiglit of cells

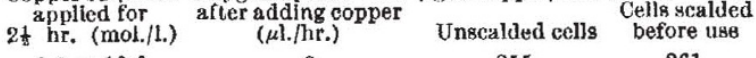

$2 \cdot 6 \times 10^{-2}$

$8.3 \times 10^{-8}$
$3.3 \times 10^{-8}$

$1.7 \times 10^{-3}$

$8.3 \times 10^{-4}$

$2.0 \times 10^{-4}$

Unscalde

$\begin{array}{rr}255 & 261 \\ 160 & 246 \\ 94 & 218 \\ 84 & 375 \\ 47 & 99 \\ 29 & <1\end{array}$

Table 2. RTSPIRATION (3 HR.) AND SORBHD COPPER (4 HR.) AFTER ADDITION OF COPPER SULPHATE TO ORLTS IN SHAKEN OR TEMPORARILY UNSHAKEN VESSELS

Applied copper Respiration Sorbed copper

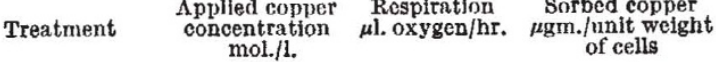

Tnshaken for first $7 \times 10^{-4}$

$2 \mathrm{hr}$. $7 j \times 10^{-4}$ $3 \times 10^{-3}$

88
7
88
100

$\sim \widetilde{0}$

108

77
193
105 the amount present in the cells. Table 2 shows the subsequent rospiration of cells treated with copper in shaken and stationary vessels and the corresponding amounts of copper sorbed. When the cells had been shaken continuously with copper, the respiration proceeded at a high level in the presence of much larger quantities of sorbed copper than those lethal to cells in stationary tubes.

Preliminary results have shown that lack of oxygen is a factor leading to high copper toxicity. When copper was shaken with cells in respirometer flasks containing hydrogen instead of air, severe and apparently irreversible inhibition of respiration occurred. While tho possibility of a change in the nature of the applied copper under anaerobic conditions cannot be excluded, two other explanations seem more likely. Possibly, internal distribution of copper in the absence of air is different from when air is present. If so, the eleven other metals tested show no similar depondence on environment. Alternatively, a respiratory system may exist under anaerobic conditions to which copper is a highly specific poison. In either case, the effect is of interest in view of the practical use of copper compounds in plant protection.

$$
\text { K. A. Hassatr }
$$

Department of Physiological Chemistry, The University, Reading.

Abbott, D. C., and Polhill, R. D. A., Analyst, 79, 547 (1954).

\section{Formation of Phenolic Substances in the Ray Parenchyma of Angiosperms}

In the course of an investigation into the origin of phenolic substances in ray parenchyma (Wardrop and Cronshaw, in preparation), it has been observed that some of these substances appeared to originate in structure limited by a double membrane, the form and dimensions of which are similar to those of amyloplasts, frequently observed in this tissue (Cronshaw and Wardrop, in preparation). Fig. 1 shows a transverse section of a ray cell from Eucalyptus elaeophora after fixation with potassium permanganate. The pattern of distribution of phenolic substances was observed to be the same after fixation with the ferrous sulphate-formaldohydo fixative for tannins described by Johansen ${ }^{1}$ although the cytoplasmic organelles were destroyed. In relatively mature material most of the cells had an appearance similar to that in Fig. 1 in which the iron staining or phenolic material showed poor fxation and penetration of tho embedding medium. In younger material from the region adjacont to the cambium it was observed that phenulic substances wcre present in vesicles onclosed within an organelle which resembled a chloroplast, the regular structure of which had been disrupted. In Fig. 2 three of these vesicles can be seen associated with lamellæ resembling the grana of normal chloroplasts. Further observations showed that theso vesicles aroso by the dissolution of starch grains within the modified chloroplast or tho amyloplast, and that as the dissolution took placo the phonolic substances were deposited around the periphery of the vosicle so formed (Fig. 3), until the whole vesicle became filled with the phenolic material (Fig. 4). At an advanced stage of differentiation the amyloplasts, or tho modified chloroplasts, could be soon to be undergoing disintegration and the released phenolic substances were aggregated in great concentration at the periphery of the vacuole (Figs. 4 and 5). In cells in which the 